DOI 10.18551/rjoas.2019-10.22

\title{
THE ANALYSIS OF EXISTENCE OF MIGRATION IN THE CONTEXT OF BASUDARA COMMUNITY IN AMBON CITY, INDONESIA
}

\author{
Matakena Fransina \\ Faculty of Social and Political Sciences, University of Pattimura, Indonesia \\ Agustang Andi \\ Makassar State University, Indonesia \\ *E-mail: sien.matakena@gmail.com
}

\begin{abstract}
Ambon city has long been a destination for migrants. The reasons for migrating aside from earning a living are also a means or way of determining access to other resources. This research described and analyzed the existence of migration in the context of the life of Basudara people in Ambon. This research used the descriptive qualitative method. The research location was Ambon City, Maluku Province. While data collection was done by observation, in-depth interviews and focused group discussion (FGD). The findings showed that the Ambon city community is very plural, multi-ethnic and open to national and international migrants. Ambon city people have local wisdom in preventing conflict and building peace. After the conflict in Ambon City, there were many migrants from various regions who came for various reasons. The economic development of the community in various fields has provided employment opportunities for migrants. Socially migrants are free to build a community in Ambon and easily they carry out religious activities. The interactions that took place between migrants and the indigenous Ambonese are very good. This could be seen from the attitude of mutual respect, and respect for fellow residents of the city of Ambon.
\end{abstract}

\section{KEY WORDS}

Migration, Basudara people, Ambon community, resources.

The study of population migration flows in the Indonesian context has so far referred to interprovincial migration or inter-island aggregation. The case of Indonesian migration shows that migration between regions is a common phenomenon. According to Wahyuni (2000), increasing population mobility not only involves the dominance of certain ethnic mobility such as the Minangkabau and Bugis people in Indonesia, but it has expanded to other ethnic groups in carrying out non-institutionalized migration. Population migration as part of population dynamics in Indonesia is more closely related to the development process that has been carried out. Migration for some people is a diversification strategy for livelihood development in an effort to get out of poverty, get a job, increase income, and obtain better public services (Skeldon, 2003; UNDP, 2009).

Migration has an impact on changes in both the short and long term on the demographic, socio-economic composition of a population both in the area of origin and destination (McFalls 2007). Generally, people move beyond social and spatial boundaries to expand their abilities and rights to improve welfare (Tirtosudarmo, 2009). They move to a place that is expected to have better economic opportunities. Differences in wages and economic structures between regions also increase the amount of migration. Lottum and Marks (2012) analyzed data from 26 provinces in Indonesia in five surveys in 1930-2000 to find that economic factors were more dominant in explaining patterns of migration between provinces in Indonesia. The development gap problem until now has happened in Ambon City. Ambon City has become the region with the most advanced development and has an impact on population mobility. Ambon City is a multi-ethnic, multi-religious city. 
Ethnic migrants to Ambon consist of Bugis, Butonese, Makassarese, Javanese, and Minang. Arrivals in Ambon City come from outside the province and within the province. Migrants from outside the province such as those from Java, Sulawesi, Bali, Kalimantan. While from within the province came from Kei Islands, Southwest Maluku, West Southeast Maluku, and Lease Island. Based on the arrival time, migrants in Ambon city are quite diverse. Some have come to Ambon for centuries with the aim of trading and broadcasting religion. After the conflict, the Ambon city community became open to pluralism and friendly to migrants.

The development of Ambon city as a city that is friendly to migrants is inseparable from the culture of the Moluccas, namely the culture of the Basudara people. connectedness in the frame of Basudara people, formed with an open attitude to accept and acknowledge differences and build cooperation, for example during the Muslim holiday and Christmas for Christians. The principle of the life of Basudara people is to create a life that is safe, peaceful, harmonious, tolerant, happy and prosperous. Being a Basudara means upholding the dignity, and maintaining peace, guaranteeing togetherness and mutual solidarity. This paper describes and analyzes the existence of migratory contexts in the life of Basudara people in Ambon.

\section{METHODS OF RESEARCH}

This research used descriptive qualitative method. Data collection was done by observation, in-depth interviews and or focused group discussion (FGD). Research location was in Ambon City, Maluku Province. The choice of location was made deliberately. Data collected included primary data and secondary data. Primary data were obtained from observations, in-depth interviews and focus group discussions (FGD). Secondary data were obtained from the Village Office and previous research reports. The selection of informants was carried out in a purposive sampling technique. Data analysis techniques were performed data collection, data analysis, data reduction, data presentation, and drawing conclusions (Neuman, 2003).

\section{RESULTS AND DISCUSSION}

Community character, wisdom, and diversity. The origin of the formation of the Ambon City community was based on the characteristics of the port city community that was built by the Portuguese and the VOC in the 16th century until the 18th century. As a port city, the anthropological character of the Ambon City community was always close to the coast. The character is also influenced by the perspective and meaning of resources. Ambon city community has a marine and land zoning system. The original character of Ambon city residents from the beginning of the city formation until now is open to differences. This openness can be seen from the attitude of accepting and recognizing differences and establishing interfaith cooperation. The character of the Ambon city community can be read from various cultural traditions and principles of daily life. Ambon city community was known as migrant, plural, and multi-ethnic society (international, national, and local) live in harmony in a frame they call Hidop Orang Basudara (Watloly, 2016).

This openness and diversity make Ambon City residents sensitive to conflict and peace-loving (hidop bae-bae), but they also maintain local wisdom in preventing conflict, conflict resolution and building peace. As a plural society, they often experience conflicts, but the ownership of capital of local wisdom that makes them will always be open to reprimand, advise each other and forgive each other fellow brothers. Maluku people or Ambonese who make the collective mind in civil society.

Hidop orang Basudara's local wisdom is formed from the interpretation of collective knowledge in each generation of the Ambon city community. Anthropologically understanding the characteristics of the Ambon City community is inseparable from the cultural system and local wisdom. To maintain their plurality, they build a brotherhood with various ethnicities, religions, islands, regions. The plurality of Ambon City society was formed by two traditions inherited in the history of this city, namely: that social plurality is a condition that is shown in 
the form of power distribution among community groups that join or are united, that sense of unity is through the basis of loyalty (cross-cutting patterned) ownership of shared values and balance of power.

For example, a City leader who always reflects the division of power between Salam and Sarane (if the Governor is from Sarane (Christian) then the Deputy must be from Salam (Islam. Likewise If the Mayor is from Sarane (Christian) then the Deputy must be from Salam (Islam), or vice versa, when Christmas arrives, the committee is formed by involving his brother Salam, and vice versa when the Eid arrives, the committee is formed by involving his brother Sarane, they will visit each other and bring each other between (bring the delivery) with fruits, food and so on during Lebaran and Christmas, the plurality of Ambon City people today should not be used as a means of triggering conflicts between Ambon City people, because they are contrary to the authenticity of the heart, character and life tradition of Ambon City residents from the past until now. this becomes a social capital and capital for the development of Ambon City building that is sustainable.

The existence of migrants in Ambon City. According to Massey et al. (1993), five main approaches that can be used to understand migration are (1) macro neo-classical economics, (2) micro neo-classical economics, (3) new economic theory, (4) labor market theory, and (5) world-system theory. According to Young (1994), migration between villages usually occurs in pre-industrial conditions because of limited transportation (long-distance). Furthermore, according to White and David (2005), two of several contributing factors are the choice of residence and employment. Migration has an impact on changes in both the short and long term on the demographic, socio-economic composition of a population both in the area of origin and destination (McFalls, 2007). The relatively low income in the area of origin is one of the reasons for migrating and moving to Ambon. The main objective is to improve life for the better and sustain life in an economic, social, political and cultural context. Although the decision to migrate is different from one another, the main reason is due to economic reasons.

The presence of migrants in Ambon city has created an Ambonese identity in the midst of diversity. Migrants who have lived in Ambon for a long time will have a crisis in resolving conflicts. Ambon City society after the conflict was flooded with many migrants coming from various regions who come with various purposes. Community economic activities in various business fields that can provide employment such as trade, industry, transportation, agriculture, mining, government, services, and others. Socially the migrants are free to build a community in Ambon and are free to carry out religious activities

The interactions that take place between migrants and the indigenous Ambonese are very good. This can be seen from the attitude of mutual respect, and respect for one another. This reality provides reinforcement in the process of social interaction, where migrants can work together such as community service, sports activities, and others carried out by the community or the Ambon government. the existence of migrants has created Orang Basudara Solidarity. The migrants retain their original identity but on the other hand, show their Ambonese identity as the Orang Basudara community. Migrants from the very beginning of their presence in Ambon have been accepted as brothers with all their original identity differences.

\section{CONCLUSION}

Ambon city community is very plural, multi-ethnic and open to the national and international migrants. Ambon city people have local wisdom in preventing conflict and building peace. In the post-conflict of Ambon city, many migrants came from various regions who came with various destinations. The economic development of the community in various fields has provided employment opportunities for migrants. Socially migrants are free to build communities in Ambon and are free to carry out religious activities. The interactions that take place between migrants and the indigenous Ambonese are very good. This can be seen from the attitude of mutual respect and respect for others. 


\section{ACKNOWLEDGEMENTS}

Our gratitude goes to the sponsor of LPDP BUDI-DN, Faculty of Social Science and Political Science of Pattimura University, as well as all parties both informants at the research location, and colleagues who helped with this research.

\section{REFERENCES}

1. Denzin, Norman K. dan Lincoln, Yvonna S, 2009, Handbook of Qualitative Research, diterjemahkan oleh Dariyatno dkk, Pustaka Pelajar, Yogyakarta.

2. Lottum J, Marks D. 2012. The determinants of internal migration in a developing country: quantitative evidence for Indonesia 1930-2000. Applied Economics 44(34): 4485-4494

3. Massey DS, Arango J, Hugo G, Kouaouci A, Pelpegrino A, Taylor JE. 1993. Theories of international migration: a review and appraisal. Population and Development Review 19(3):431-466.

4. McFalls Jr JA. 2007. Maret. Population. A lively introduction. Population Bulletin 62(1). http://www.prb.org/pdf07/62.1livelyintroduction.pdf.

5. Mc Cann P. 2013. Modern urban and regional econommics. Oxford (UK): Oxford University Pr.

6. Skeldon R. 2008. Migration and development: a global perspective. London (UK): Longman.

7. Tirtosudarmo R. 2009. Mobility and human development in Indonesia. Human Development Research Paper 2009/19. Human Development Reports Research Paper. United Nations Development Programme.

8. United Nations Development Programme. 2009. Human development report 2009 overcoming barriers: human mobility and development. New York (US): United Nations Development Programme.

9. Wahyuni ES. 2003. Mobilitas Penduduk dan Otonomi Daerah. Mimbar Sosek. Jurnal Sosial-Ekonomi Pertanian.

10. Watloly A (2016). Perdamaian Berbasis Adat Orang Basudara. Yogyakarta, PT Kanisius.

11. White MJ, David PL. 2005. Internal Migration. In Handbooks of Population: Handbooks of Sociology and Social Researh. Poston DL and Miclin M. (Edited). America (US): Kluwer Academic/Plenum Publiser.

12. Young E. 1994. Internal Migration. Lucas D, Meyer P. Editors. In Beginningpopulation studies. Edisi ke-2. Canberra (AU): National Center for Development Studies - ANU. 199 hal. 